difficulties in maintaining their own services. As a result, their participation in supporting and influencing private institutions is decreasing - a significant problem in cities where private colleges are the only higher education institutions. Further, there are no clear incentives for local businesses to invest or sponsor these schools, as their higher education sponsorship entitles them to only a limited tax deduction.

A substantial part of foundation school budgets is generated by tuition fees. Per semester tuition fees are autonomously determined by each school, the highest reaching about 200 percent of the average monthly salary. According to the 1996 Personal Income Tax Code, students or parents may deduct 30 percent of the amount state institutions charge as tuition from their taxable incomes, irrespective of whether tuition is paid in private or public schools. Private colleges do not pay taxes on tuition, but do on other revenues.

The 1997 white paper on higher education describes a coherent government development policy over the medium term (1997-2002). The paper assigns an important role to the development of private higher education, which should greatly contribute to an expansion of enrollments as well as competition in market-oriented fields of study. Nevertheless, only time will determine whether present or future governments can collect enough political leverage to implement these goals.

\section{Private Higher Education Development in China}

\section{Yang Rui}

Yang Rui is a doctoral student at the School of Social and Policy Studies in Education, University of Sydney. Address: Faculty of Education, University of Sydney, NSW 2006, Australia.

$\mathrm{P}$ rivatization in the field of higher education is a recent and recurrent phenomenon. In China, private higher education disappeared in 1952. Today, it has been resurrected as an offshoot of the country's newfound economic expansion and diversification. Skeptics are beginning to take notice of this resurgence.

\section{Theoretical Perspectives}

The growth in Chinese private higher education has created many potential problems and provoked intense debate among interested parties on various theoretical and practical concepts. An early discussion of this topic was offered in 1987 by Pan Maoyuan. In his book Problems and Prospects of Public and Private Higher Education Systems, he considers the relationship between the public and private sectors of China's higher education system. ${ }^{1}$ It is clear that he highly values China's newly emerging, private higher education institutions because they benefit society, encourage educational fund raising, make use of intellectual resources, and serve as a means by which to recruit qualified teachers.

Private education has become an important area of inquiry in Chinese educational research.

Pan's observations quickly inspired other opinions. For example, a 1988 article by G. Z. Qin and R. Yang reviews the phenomenon of private funding in modern Chinese higher education, concluding that the rise of private higher education will be a challenge for China's higher education system. $^{2}$

Wei Yitong makes the point that only by making use of the independent and flexible features of private higher education can the sector foster strengths and circumvent weaknesses. He concludes by urgently appealing for recognition of private higher education. ${ }^{3}$

Private education has become an important area of inquiry in Chinese educational research. In this effort, Xiamen University's Institute of Higher Education was mandated by China's State Education Commission to explore private higher education legislation. Their findings, outlined in the book Studies in Nongovernmental Higher Education, represent the first attempt to discuss the emergence, development and future trends of nongovernmental higher education in China. The book inspired a spirited debate on the subject. ${ }^{4}$

Most researchers accept the notion that the reappearance of private higher education in China is a direct result of the emerging market economy. ${ }^{5}$ Most agree that laws are required to officially recognize private higher education as an integral part of the education system.

\section{Media Opinions}

Private higher education in China is a not yet officially accepted, but growing, phenomenon. As a result, people have formed various opinions concerning its efficacy. In this effort, many rely heavily on the press to investigate new developments in private higher education.

Among active reporters, Yang Zhihan is the most prominent. He shows a concern for private higher education in China. Between January 1988 and January 
1989, Yang published nine reports on the topic of private schools. His writings, although not academic, are significant for their impact on both government and public opinion.

\section{People are often puzzled by the diffi- cult situation facing private higher edu- cation development in China.}

These media opinions generated great pressure in certain academic departments. Due to the complexity of China's private higher education system and concerns with potentially disturbing planned readjustments, a ban was placed on publishing reports in the major newspapers.

\section{Official Misgivings}

People are often puzzled by the difficult situation facing private higher education development in China. Although the constitution and the Central Committee of the Chinese Communist Party have explicitly stipulated their support of nonpublic schools, private higher education development has always been in an ambiguous position. This is mainly a by-product of skepticism on the part of administrative bodies potentially affected by such changes, which have instituted excessive rules and regulations, and adopted a wait-and-see attitude.

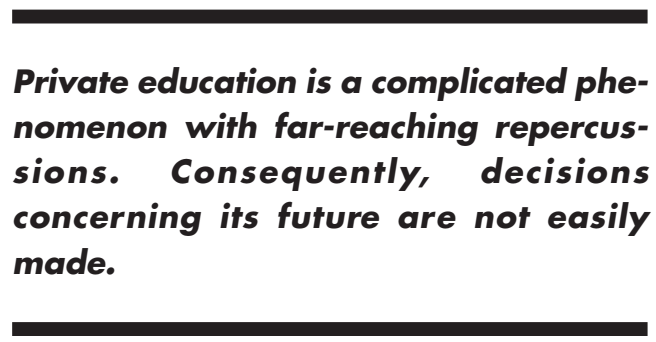

In 1981, China's Ministry of Education completed a report on strengthening the leadership and administration of private continuation schools. In 1988, the ministry issued a set of "Provisional Regulations on the Establishment of Schools by Social Forces." These documents clearly show the negative attitude held by the State Education Commission toward private higher education. In response to these reports, some administrators have suggested that a series of laws governing private schools be established so that private school operations might be standardized. Top administrators argue that China's current private higher institutions of learning are unable to accomplish their goals and often encounter financial difficulties. Other administrators deny the advantages of private higher education from another perspective, believing that China's higher education system is already too vast, and that the state is hardly able to support public higher learning institutions.

Private education is a complicated phenomenon with farreaching repercussions. Consequently, decisions concerning its future are not easily made. The State Education Commission worries that private higher learning institutions will encounter financial problems, requiring that they turn to the state for financial assistance. Additional concerns include the character and quality of national higher education, whether or not its scope is adequate, and student assignment pressures. Before solutions to these problems are settled upon, the existing bureaucracy is loathe to make definite policy decisions concerning private higher education. Nevertheless, change is in the works, and China's existing private higher education institutions have raised important questions concerning many aspects of country's current education and social needs.

\section{Notes}

1. M.Y. Pan, "Problems and Prospects of Public and Private Higher Education System," in Studies in Private Higher Education, ed. Y.T. Wei and Z. Y. Li (Xiamen: Xiamen University Press, 1991a). (in Chinese)

2. G. Z. Qin and R. Yang, "Private Higher Education in the People's Republic of China: A Silent Resurgence," in International Review of Education, 39(5) (1993): 438442. (in Chinese)

3. Y. T. Wei, "On the Status and Function of Nongovernmental Higher Education," Higher Education Research 2, (1989): 79-85. (in Chinese)

4. Y. T. Wei and Z. Y. Li. eds., Studies in Private Higher Education (Xiamen: Xiamen University Press, 1991). (in Chinese)

5. M. Y. Pan, "Some Considerations of the Nongovernmental Higher Education System," in Studies in Private Higher Education.

\section{Higher Education on the WWW}

The Boston College Center for International Higher Education's website, at http://www.bc.edu/bc_org/ avp/soe/cihe/Center.html, continues to grow and improve. Recent additions include feedback forms, current news of the Center, complete text of all issues of International Higher Education, and new online resources and links. Our website has received awards of recognition from Point Communications and the InterNIC Academic Guide to the Internet, and serves as a valuable resource for information on comparative and international higher education. 